\title{
Factor Affecting Customer's Intention to Use Mobile Banking Service at Private Bank in Indonesia
}

\author{
Richman Tumpal Micael Pakpahan ${ }^{1}$, Nilo Legowo ${ }^{2 *}$ \\ ${ }^{1}$ Richman Tumpal Micael Pakpahan. Master Student. Information Systems Management Department, \\ BINUS Graduate Program - Master of Information Systems Management, Bina Nusantara University, \\ Jakarta, Indonesia. Email: richman.pakpahan@binus.ac.id \\ ${ }^{2}$ Nilo Legowo². Information Systems Management Department, BINUS Graduate Program-Master of \\ Information Systems Management, Bina Nusantara University, Jakarta, Indonesia,. Email: \\ nlegowo@binus.edu
}

Article History: Received: 10 November 2020; Revised 12 January 2021 Accepted: 27 January

2021; Published online: 5 April 2021

\begin{abstract}
The rapid development of technology in Indonesia today resulted in very tight competition in the industrial world, where industry players are required to be able to provide faster and efficient services to keep their consumers from turning to competitors. PT. XYZ Bank In 2014 launched a mobile banking service called SimobiPlus. However, based on the data obtained from the number of internal SimobiPlus users, it is still below $15 \%$ of the total customers and it can be concluded that the use intention between customers is still very low, so the authors want to find out the factors that influence the user's intention to use. These research analysts used the method of the previous research UTAUT Extend, where this method has been proven on conducting research of intended use and modify it by adding a variable perception of usefulness, ease of use, trust, and security. In collecting the data, questionnaires with 400 respondents also use for the analysis of this research. Based on the results, the variable Perceived Ease of Use, Trust, Security, Social Influence has a positive effect on behavioral intention, where the Perceived Usefulness variable has the top influence among the variables used in this research.
\end{abstract}

Keywords: Mobile Banking, Behaviour Intention, UTAUT, SEM PLS, Bank

\section{Introduction}

Mobile banking is one of the services provided by banks as a result of rapid technological developments that have resulted in competition in the banking industry to meet the demands of customers who want fast, safe, and efficient services. With the existence of mobile banking services, it has made it easier for customers to carry out banking transactions where at first the customer had to go to the branch office to use the service facilities provided by banking. This is supported by the development of smartphone technology which also has a positive impact on the development of mobile banking. Based on the results of a survey of smartphone users from 2016 with a total of 65.2 million users and increasing to 55\% in 2019 with a total of 92 million (Data, 2019). Seeing the high number of smartphone usage, banks can use this opportunity to develop mobile banking services to increase customer loyalty.

The adoption of technology in mobile banking services was also carried out by the bank PT. XYZ Bank. This bank has launched a mobile banking application called SimobiPlus. The Simobiplus application is expected to be able to improve relationships with users through a series of existing features so that any problems experienced by users can be resolved easily and quickly. Although the Simobiplus mobile banking service has provided convenience in conducting banking transactions, based on data obtained from the bank's internal party, it shows that the level of application usage is still very low accompanied by total data acquisition for the period 2019-2020 that does not meet the target set by the parties. management so that a review is needed by looking at the behavioral intention to use customers.

This research aims to determine the factors that influence behavioral intention to use SimobiPlus mobile banking services. In preparing the research model used will refer to previous research models that use the TAM and UTAUT models (Gharaibeh \& Mohd Arshad, 2018)(Luarn \& Lin, 2005)(Shanmugam et al., 2014) and the addition of variable security and trust. UTAUT research model has six constructs are Expectancy performance, Effort Expectancy, Social effects, Facilitating Condition, behavioral intention to use, and usage behavior to measure the level of acceptance of a system (Venkatesh et al., 2011). besides the research model, TAM has perceived usefulness and perceived ease of use (Davis et al., 1989). In digital financial transactions, security is a 
significant factor in increasing behavioral intention to use mobile banking (Sindhu Singh, 2018) and a sense of trust also dominates to support behavioral intention to use mobile banking.

\section{Literature Review}

\subsection{Mobile Banking}

Barnes, Stuart and J Corbitt, Brian defines mobile banking as a banking channel that can be accessed by customers using cell phones, PDAs, and smartphones(Barnes \& Corbitt, 2003). Technological advances also have an impact on the development of mobile banking technology because it makes it easier to digitize and automate banking services (Bradley \& Stewart, 2002). The rapid development of mobile phone technology, such as smartphones, has given birth to mobile app technology that has changed mobile banking services. Mobile banking technology has changed banking services where traditional mobile banking technology only provides limited services (Wessels \& Drennan, 2010). With the use of mobile banking services found on smartphones, almost all services provided can be accessed easily by customers.

\subsection{Technology Acceptance Model (TAM)}

Tam is a research model proposed by (Davis et al., 1989) in 1989 that is in the adaptation of the theory of reasoned action (TRA) is the theoretical model that explains the receipt of new information users of technology. TRA explains that a person's intention is influenced by individual norms and attitudes where attitudes are influenced by their beliefs (I Ajzen \& Fishbein, 1980). Of the many existing research models, Tam is a research model that is most widely accepted and used by researchers related to information systems (Agarwal \& Prasad, 1999). The TAM model is used for research on information systems. This model proposes two factors that influence the intention to use the system, id est perceived usefulness and perceived ease of use. Perceived usefulness is defined as a person's level of confidence that using a particular system can improve their performance, while ease of use is defined as the extent to which a person believes that using a specific system is not complicated and does not require complex training (Luarn \& Lin, 2005) The variables used in the research model in this study are perceived usefulness and perceived ease of use.

\subsection{Unified theory of acceptance and use of technology (UTAUT)}

The UTAUT research model was developed by (Venkatesh et al., 2003) to predict user adoption of information technology. This model is a combination of TAM, social cognitive theory (Bandura, 1991), IDT (Rogers \& Monsell, 1995), the theory of reasoned action (TRA) (Fishbein \& Ajzen, 1977), a theory of planned behavioral (TPB) (Icek Ajzen, 1991), and TC. With empirical analysis, Venkatesh and his team found that performance expectancy, effort expectancy, social influence and facilitating conditions, gender, age, experience, the voluntariness of use are the main factors determining whether users will use a system. Analysis in this research using social Influence variables that are interpreted as variables that affect people or the environment closest to using a system and behavioral intention variables that explain the level of user intention in using a system.

\subsection{Research Model Formation}

The formation of this research model proposes a model of previous research theory in which the model has been proven and used by previous researchers in research related to the intention of use in mobile banking services such as TAM (Davis, 1989), UTAUT (Venkatesh et al., 2003) by adding the perceived ease of use variable (Davis, 1989) is a variable to measure the extent to which one believes that using a system will be free from effort. Also based on the theory (Sindhu Singh, 2018) suggesting that social influence variables also affect the user's intentions in mobile banking services, this is supported by previous research that states if one can influence the surroundings to use the system then the person will follow. Security is defined as a threat that creates circumstances, conditions, or events that have the potential to cause economic difficulties to network data or resources in the form of destruction, disclosure, data modification, denial of service and fraud, waste, and abuse according to theory (Sindhu Singh, 2018), as well as for the theory (Gharaibeh \& Mohd Arshad, 2018) which mentions that trust is a variable of positive influence on behavioral intention. The factor about trust is written by (Gharaibeh \& Mohd Arshad, 2018) that certain transactions are by consumer expectations and based on previous research if trust has a positive effect on behavioral intention. And finally, in a variable (Davis, 1989)that perceived usefulness refers to the increase produced by using a particular system, this is supported by further research if Perceived Usefulness has a positive variable as well. These factors already refer to the improvements produced by using a particular system these factors already refer to the increase generated by using certain systems Based on previous research concluded that perceived ease of use has a positive influence on intention to use, based on this, the authors propose a hypothesis:

- H1: Perceived ease of use (PEOU) influences behavioral intention. 
- H2: Social Influence (SI) influences behavioral intention.

- H3: Security (S) influence behavioral intention.

- H4: Trust (T) influences behavioral intention.

- H5: Perceived Usefulness (PU) influence behavioral intention.

\section{Research Methodology}

\subsection{Research Framework}

Model framework research that is used containing two of the research model TAM and UTAUT, that is perceived ease of use, perceived usefulness, and also a social influence as well as added variable security and variable Trust which is where the variable is not present in the model of the research.

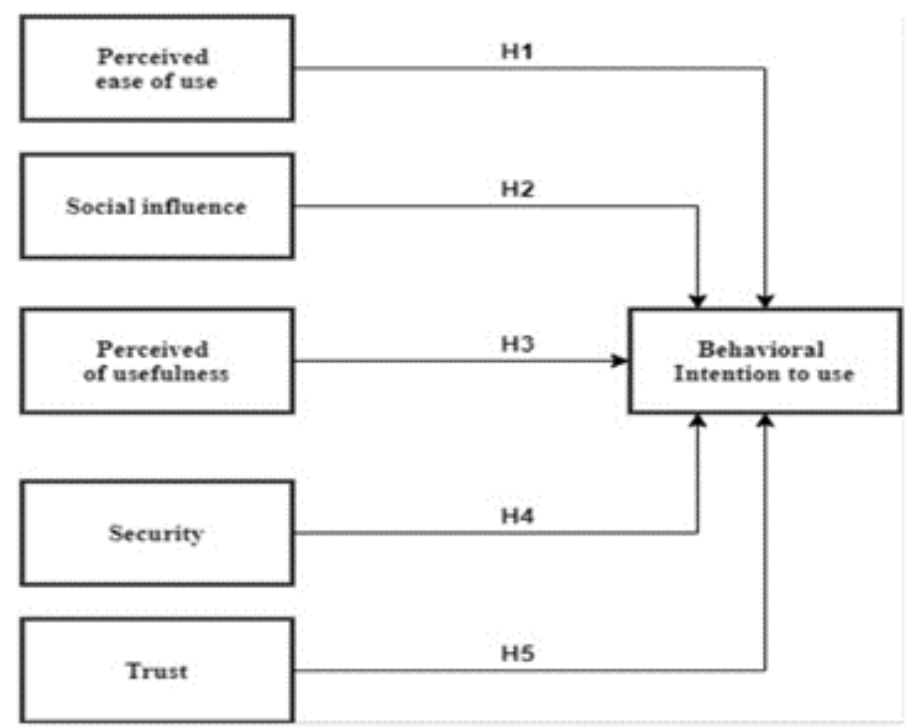

\subsection{Structural Model}

Figure 1. Research Model

Based on figure 1 research model has a relationship between variables which consists of Perceived Ease of Use (X1), Social Influence (X2), Security (X3), Trust (X4), Perceived Usefulness (X5) positive influence to Behavioral Intention (Y1). From the relation of the variables can be seen that the regression equation as follows:

$$
\mathrm{Y} 1=\beta 1+\beta 2 \mathrm{X} 1+\beta 3 \mathrm{X} 2+\beta 4 \mathrm{X} 3+\beta 5 \mathrm{X} 4+\beta 6 \mathrm{X} 5+\mathrm{E} 1
$$

Based on the hypothesis that is in accordance with the regression equation above, this study will prove whether the results of each $\beta i=0$ or $\beta i \neq 0.1$.

- Variable Perceived Ease of Use (X1) has a positive effect on the variable of Behavioral Intention (Y1) so that it can be formulated as follows:

$\mathrm{H} 0: \beta 1=0$

Ha: $\beta 1 \neq 0$

- Variable Social Influence (X2) has a positive effect on the variable of Behavioral Intention (Y1) so that it can be formulated as follows:

$\mathrm{H} 0: \beta 2=0$

Ha: $\beta 2 \neq 0$

- Variable Security (X3) has a positive effect on the variable of Behavioral Intention (Y1) so that it can be formulated as follows:

$\mathrm{H} 0: \beta 3=0$

Нa: $\beta 3 \neq$ 
- Variable Trust (X4) has a positive effect on the variable of Behavioral Intention (Y1) so that it can be formulated as follows:

$$
\begin{aligned}
& \text { H0: } \beta 4=0 \\
& \text { На: } \beta 4 \neq 0
\end{aligned}
$$

- Variable Perceived Usefulness $(\mathrm{X} \neg 5)$ has a positive effect on the variable of Behavioral Intention (Y1) so that it can be formulated as follows:

$$
\begin{aligned}
& \text { H0: } \beta 5=0 \\
& \text { Нa: } \beta 5 \neq 0
\end{aligned}
$$

\subsection{Survey}

data collection, the authors use a survey as one of the data to be used as research support material. By distributing online questionnaires to 400 respondents via Google Forms to the public. The questionnaire was distributed through social media applications such as WhatsApp, Instagram, and Facebook. Respondents drawn in this study focused on the scope of Jakarta and its surroundings. The questionnaire measurement data consists of 22 questions and uses a liker scale.

\subsection{Survey}

The population in this study used 82245 mobile banking users in the DKI Jakarta area. The error rate used is $5 \%$, it can be concluded that the total number of samples to be used in this study is 400 people as the sample.

\subsection{Respondents Demographic}

Questionnaire respondents in this study consisted of men and women. Based on the number of respondents in the questionnaire, the largest number of mobile banking service users were filled by men (63\%). Most of the last education carried out by respondents was carried out at 7 levels, namely SLTP, SLTA, Diploma I, Diploma II, Diploma III, Diploma IV / Strata I, and Strata II still dominating from Diploma IV / Strata I this is because the higher the education, the knowledge of technology is growing. While the demographics of respondents last based on the intensity of the SimobiPlus showed that (49\%) answered sometimes This shows that the intensity SimobiPlus in support of the financial system relatively less than the maximum and therefore the author makes this study intending to find out and describe more in related factor- what factors influence the user's intention to use mobile banking technology.

It can be seen from the table that all variables towards behavioral intention are tested by looking at the value of Cronbach's Alpha and Composite Reliability where the assessing indicator must have a value of $>0.6$, based on the table that all of these variables are declared reliable.

\section{Result and Discussion}

\subsection{Validity and Reliability}

The data to be analyzed is obtained using a questionnaire method where the questionnaire method uses the indicators in Appendix 1. This research test using SMARTPLS. Validity testing is a form of testing the extent of accuracy and truth as a measuring tool for research variables. The validity test is carried out by looking at the loading factor value where the indicator for each value must have> 0.7 (Munoz-Leiva et al., 2017) and it can be said to be valid, and can also be done by looking at the Average Variance Extracted (AVE) value at each value variables must have a value> 0.5 (Cheung \& Wang, 2017) to be able to state that the variable is valid. 
Table 1. Loading Factor Analysis Result

\begin{tabular}{|c|c|c|c|}
\hline $\begin{array}{l}\text { Variable } \\
\text { Indicators }\end{array}$ & $\begin{array}{l}\text { Nilai Outer } \\
\text { Loading }\end{array}$ & $\begin{array}{l}\text { Limit } \\
\text { Value }\end{array}$ & Result \\
\hline \multicolumn{4}{|c|}{ Perceived Ease of Use } \\
\hline $\mathrm{X} 1.1$ & 0.850 & $\geq 0.7$ & Valid \\
\hline $\mathrm{X} 1.2$ & 0.860 & $\geq 0.7$ & $\underline{\text { Valid }}$ \\
\hline $\mathrm{X} 1.3$ & 0.856 & $\geq 0.7$ & $\underline{\text { Valid }}$ \\
\hline \multicolumn{4}{|c|}{ Social Influence } \\
\hline $\mathrm{X} 2.1$ & 0.812 & $\geq 0.7$ & Valid \\
\hline $\mathrm{X} 2.2$ & 0.835 & $\geq 0.7$ & Valid \\
\hline $\mathrm{X} 2.3$ & 0.840 & $\geq 0.7$ & Valid \\
\hline \multicolumn{4}{|l|}{ Security } \\
\hline X3.1 & 0.799 & $\geq 0.7$ & Valid \\
\hline X3.2 & 0.845 & $\geq 0.7$ & Valid \\
\hline X3.3 & 0.846 & $\geq 0.7$ & Valid \\
\hline
\end{tabular}

\begin{tabular}{|c|c|c|c|}
\hline $\begin{array}{l}\text { Variable } \\
\text { Indicators }\end{array}$ & $\begin{array}{l}\text { Nilai Outer } \\
\text { Loading }\end{array}$ & $\begin{array}{l}\text { Limit } \\
\text { Value }\end{array}$ & Result \\
\hline \multicolumn{4}{|l|}{ Trust } \\
\hline $\mathrm{X} 4.1$ & 0.804 & $\geq 0.7$ & Valid \\
\hline $\mathrm{X} 4.2$ & 0.845 & $\geq 0.7$ & Valid \\
\hline $\mathrm{X} 4.3$ & 0.850 & $\geq 0.7$ & Valid \\
\hline \multicolumn{4}{|c|}{ Perceived Usefulness } \\
\hline X5.1 & 0.824 & $\geq 0.7$ & Valid \\
\hline $\mathrm{X} 5.2$ & 0.855 & $\geq 0.7$ & Valid \\
\hline $\mathrm{X} 5.3$ & 0.844 & $>0.7$ & Valid \\
\hline \multicolumn{4}{|c|}{ Behavioral Intention (BI) } \\
\hline Y1.1 & 0.871 & $>0.7$ & Valid \\
\hline Y1.2 & 0.842 & $>0.7$ & Valid \\
\hline Y1.3 & 0.938 & $>0.7$ & Valid \\
\hline
\end{tabular}

Table 2. Average Variance Extracted (AVE) Analysis Result

\begin{tabular}{|c|c|c|c|}
\hline Variable & AVE & $\begin{array}{l}\text { Limit } \\
\text { Value }\end{array}$ & Result \\
\hline Behavioral intention (BI) & 0.783 & $\geq 0.5$ & Reliable \\
\hline Perceived Ease of Use & 0.731 & $\geq 0.5$ & Reliable \\
\hline Perceived Usefulness & 0.708 & $\geq 0.5$ & Reliable \\
\hline Security & 0.690 & $\geq 0.5$ & Reliable \\
\hline Social Influence & 0.687 & $\geq 0.5$ & Reliable \\
\hline Trust & 0.695 & $\geq 0.5$ & Reliable \\
\hline
\end{tabular}

Based on table 1 , it is conclusive that all variables have a value above $>0.7$ for calculation using loading factor, and table 2 tested using Average Variance Extracted (AVE) that each variable indicator has a value above $>0.5$ inferred the whole variable is declared valid. Testing can also be done through Reliability Test through Cronbach's Alpha value and Composite Reliability value. For Cronbach's Alpha value has a provision that the value is $>0.6$ (Sindhu Singh, 2018) and can be said to be reliable, for composite reliability value where the value provision has $>0.6$ (Fornell \& Larcker, 1981) then it is said reliable.

Table 3. Reliability Test Result

\begin{tabular}{|c|c|c|c|}
\hline Variable & $\begin{array}{c}\text { Cronbach's } \\
\text { Alpha }\end{array}$ & $\begin{array}{c}\text { Composite } \\
\text { Reliability }\end{array}$ & Result \\
\hline $\begin{array}{c}\text { Perceived } \\
\text { Ease of Use }\end{array}$ & 0.816 & 0.891 & Reliable \\
\hline $\begin{array}{c}\text { Perceived } \\
\text { Usefulness }\end{array}$ & 0.793 & 0.879 & Reliable \\
\hline Security & 0.775 & 0.869 & Reliable \\
\hline $\begin{array}{c}\text { Social } \\
\text { Influence }\end{array}$ & 0.772 & 0.868 & Reliable \\
\hline Trust & 0.780 & 0.872 & Reliable \\
\hline
\end{tabular}




\begin{tabular}{|c|c|c|c|}
\hline Variable & $\begin{array}{c}\text { Cronbach's } \\
\text { Alpha }\end{array}$ & $\begin{array}{c}\text { Composite } \\
\text { Reliability }\end{array}$ & Result \\
\hline $\begin{array}{c}\text { Behavioral } \\
\text { intention (BI) }\end{array}$ & 0.865 & 0.915 & Reliable \\
\hline
\end{tabular}

The entire variable on table 3 against behavioral intention through testing by looking at Cronbach's Alpha and Composite Reliability values where the assessor indicator must have a value of $>0.6$, based on the table concluded that the entire variable is declared reliable.

\subsection{Hypothesis Analysis}

The results of the study showed that the overall variable is said to have a significant influence when calculated using a p-value value $<0.05$.

Table 4. Hypothesis overall results

\begin{tabular}{|c|c|c|c|c|c|c|c|}
\hline Variable & $\begin{array}{c}\text { Original } \\
\text { Sample } \\
(\mathrm{O})\end{array}$ & $\begin{array}{c}\text { Sample } \\
\text { Mean } \\
(\mathrm{M})\end{array}$ & $\begin{array}{c}\text { Standard } \\
\text { Deviation } \\
(\text { STDEV })\end{array}$ & $\begin{array}{c}\text { T Statistics } \\
(\mid \mathrm{O} / \mathrm{STDEV})\end{array}$ & $\begin{array}{c}\text { critical } \\
\text { t-values }\end{array}$ & P Values & Result \\
\hline H1 & 0.159 & 0.156 & 0.047 & 3.353 & 1.96 & 0.001 & positive effect \\
\hline H2 & 0.198 & 0.195 & 0.042 & 4.727 & 1.96 & 0.000 & positive effect \\
\hline H3 & 0.171 & 0.175 & 0.041 & 4.201 & 1.96 & 0.000 & positive effect \\
\hline H4 & 0.222 & 0.223 & 0.043 & 5.154 & 1.96 & 0.000 & positive effect \\
\hline H5 & 0.258 & 0.260 & 0.046 & 5.594 & 1.96 & 0.000 & positive effect \\
\hline
\end{tabular}

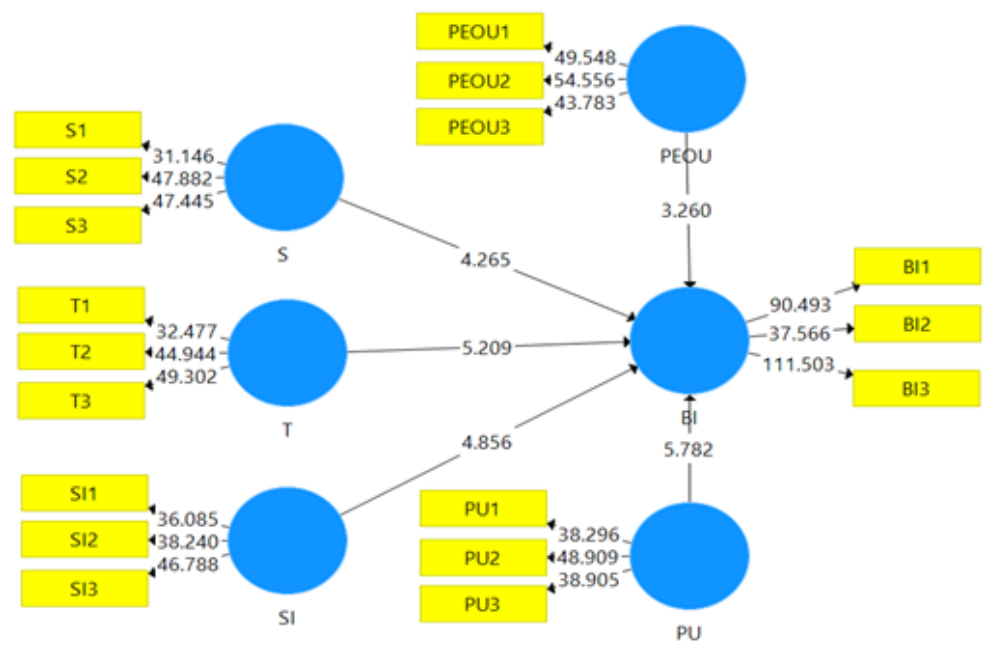

Figure 2. Bootstrapping Result Source: Author data

The results of this study indicate that all of these variables are said to have a positive influence on behavioral intention if the calculation is carried out using a p-value < 0.05) and t-table. Calculation through critical t-values on the degree (df) is obtained by calculating the formula using Excel as follows: TINV $(0.05 ; 394)$, the result is 1,96. The criteria for acceptance or rejection of a hypothesis using at table are:

- If t statistic < critical t-values (1.96), then Ho is accepted and Ha is rejected.

- If t-statistic> critical t-values (1.96), then Ho is rejected and Ha is accepted. 


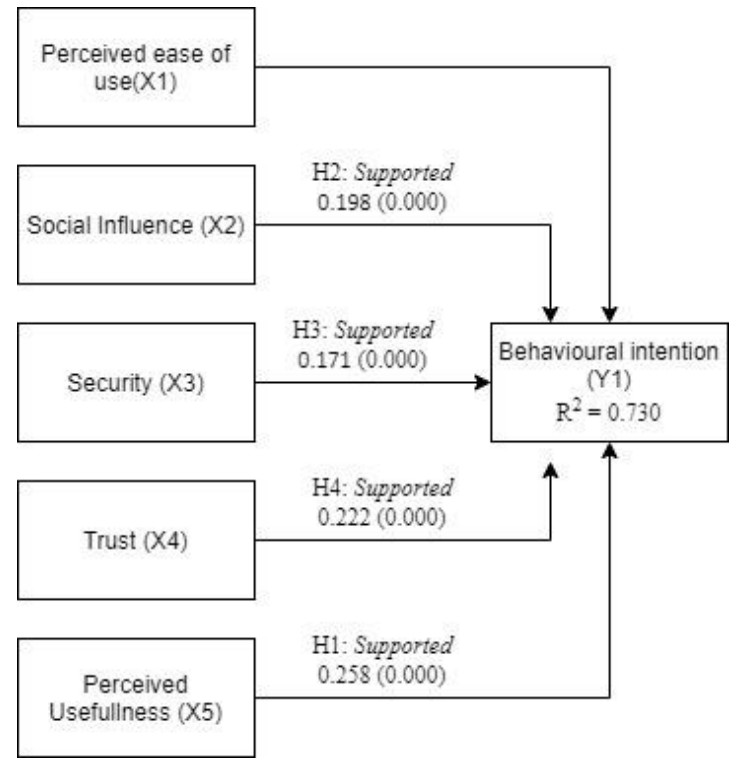

Figure 3. Structural Model

Variable Perceived Usefulness has a positive effect on behavioral intention has a value of $\beta=0,258$ and $p$ value $=0,000$ concluded as the variable with the highest value of the four variables. This is due to the intention of users of mobile banking services to increase the use of these services. It is therefore suggested to the banking company to pay attention to and improve the features that can help customers in using banking services as well as minimize the loss that will be experienced by the customer in the use of mobile banking.

Perceived Ease of Use has a positive effect on behavioral intention according to the results shown in table 4.4 that the value of $\beta=0.159$, the value of $p$-value $=0.001$ when compared with the $t$-table, the value of $t$ statistical $>t$ table 1.966). This, Ha was accepted and Ho was rejected. Because these variables are considered by the public, if the use of technology can be studied easily, it can increase customer interest in continuing to use mobile banking services. It is hoped that the banking management will simplify how to use the mobile banking system provided to increase the intention to use mobile banking.

Social Influence also has a positive influence on the behavioral intention of mobile banking services. This result is in accordance with the value shown $\beta=0.198$, the $p$-value $=0.000$, when compared with the $t$-table, the $\mathrm{t}$ statistical value $>\mathrm{t}$ table $(4,727>1,966)$ is obtained. Thus, it is found that $\mathrm{Ha}$ is accepted and Ho is rejected. It is considered by the public that social influence has sufficient influence to increase customer interest in using mobile banking services, especially if it is influenced by promotions that can attract public attention through mass media and influenced by the surrounding environment where many people use the service.

Behavioral Intention in mobile banking services is also positive influenced by the Security variable. These results are following those indicated by the value of $\beta=0.222$ and the $p$-value $=0.000$ when compared with the $\mathrm{t}$-table, then the $\mathrm{t}$ statistical value $>\mathrm{t}$ table $(4.201>1.966)$ is obtained. Based on these results Ha can be accepted and $\mathrm{Ho}$ is rejected. That this security variable has a very positive effect on banking transactions because customers feel that transactions using digital finance are considered safer. Therefore, banking companies must be able to improve and pay attention to security in the use of mobile banking services in preventing leakage of data privacy owned by customers.

The latest research results for the Trust variable where this variable has a positive influence on behavioral intention to mobile banking services. This is indicated by the results of the value of $\beta=0.222$, the $p$-value $=$ 0.000 , and when compared with the $t$-table, the $t$-statistic value $>t$ table $(5.154>1,966)$ is obtained. Thus, it is found that $\mathrm{Ha}$ is accepted and $\mathrm{Ho}$ is rejected. This variable presents that intention to use arises because a sense of trust can increase customer intention to use mobile banking. Although mobile banking is new communication technology, trust in banking has been built for a long time, marked by previous successful experiences with conventional banking. The customer assesses that his trust in a banking service will be in line with consumer expectations, such as mobile banking will deliver every need in online transactions. To increase this sense of trust, banking companies need to convince customers to ensure that every online transaction carried out is free from fear, fraud, and potential risks that will be experienced by customers in the future. Now therefore banking firms need to improve and noticed a sense of confidence (trust) as do the testing the security of mobile banking services to increase the sense of trust for customers to use mobile banking services such as well as perform 
routine maintenance application to avoid the bugs out of the application system and improve the taste comfortable in using the application.

\section{Conclusion}

It was concluded that the studied variables for this study were an overall positive influence on behavioral intention on the mobile banking service. The factor of perceived ease of use has a positive influence on behavioral intention, the perceived usefulness factor also has positive influence on behavioral intention, then the security factor and the trust factor have a positive effect on behavioral intention. The last factor that affects behavioral intention is Social Influence. All these variables turned out to show different values depending on the test. Because from these results an explanation can be given regarding what extent these variables affect behavioral intention to mobile banking services.

\section{References}

[1]. Agarwal, R., \& Prasad, J. (1999). Are Individual Differences Germane to the Acceptance of New Information Technologies? Decision Sciences, 30(2), 361-391. https://doi.org/10.1111/j.1540-5915.1999.tb01614.x

[2]. Ajzen, I, \& Fishbein, M. (1980). Understanding attitudes and predicting social behaviour. http://www.citeulike.org/group/38/article/235626

[3]. Ajzen, Icek. (1991). The theory of planned behavior. Organizational Behavior and Human Decision Processes, 50(2), 179-211.

[4]. Bandura, A. (1991). Social cognitive theory of moral thought and action. Handbook of Moral Behavior and Development, 1, 45-103.

[5]. Barnes, S. J., \& Corbitt, B. (2003). Mobile banking: concept and potential. International Journal of Mobile Communications, 1(3), 273-288. https://doi.org/10.1504/IJMC.2003.003494

[6]. Bradley, L., \& Stewart, K. (2002). A Delphi study of the drivers and inhibitors of Internet banking. International Journal of Bank Marketing, 20(6), 250-260. https://doi.org/10.1108/02652320210446715

[7]. Cheung, G. W., \& Wang, C. (2017). Current approaches for assessing convergent and discriminant validity with SEM: Issues and solutions. Academy of Management Proceedings, 2017(1), 12706.

[8]. Data, K. (2019). Pengguna Smartphone di Indonesia 2016-2019. Diakses Dari Https://Databoks. Katadata. Co. Id/Datapublish. Pada April.

[9]. Davis, F. D. (1989). Information Technology Introduction. 13(3), 319-340.

[10]. Davis, F. D., Bagozzi, R. P., \& Warshaw, P. R. (1989). User Acceptance of Computer Technology: A Comparison of Two Theoretical Models. Management Science, 35(8), 982-1003. https://doi.org/10.1287/mnsc.35.8.982

[11]. Fishbein, M., \& Ajzen, I. (1977). Belief, attitude, intention, and behavior: An introduction to theory and research.

[12]. Fornell, C., \& Larcker, D. F. (1981). Structural equation models with unobservable variables and measurement error: Algebra and statistics. Sage Publications Sage CA: Los Angeles, CA.

[13]. Gharaibeh, M. K., \& Mohd Arshad, M. R. (2018). Determinants of intention to use mobile banking in the North of Jordan: Extending UTAUT2 with mass media and trust. In Journal of Engineering and Applied Sciences (Vol. 13, Issue 8, pp. 2023-2033). https://doi.org/10.3923/jeasci.2018.2023.2033

[14]. Luarn, P., \& Lin, H. H. (2005). Toward an understanding of the behavioral intention to use mobile banking. Computers in Human Behavior, 21(6), 873-891. https://doi.org/10.1016/j.chb.2004.03.003

[15]. Munoz-Leiva, F., Climent-Climent, S., \& Liébana-Cabanillas, F. (2017). Determinants of intention to use the mobile banking apps: An extension of the classic TAM model. Spanish Journal of MarketingESIC, 21(1), 25-38.

[16]. Rogers, R. D., \& Monsell, S. (1995). Costs of a predictible switch between simple cognitive tasks. Journal of Experimental Psychology: General, 124(2), 207.

[17]. Shanmugam, A., Savarimuthu, M. T., \& Wen, T. C. (2014). Factors affecting Malaysian behavioral intention to use mobile banking with mediating effects of attitude. Academic Research International, 5(2), 236-253.

[18]. Sindhu Singh, R. . S. (2018). Article information: Predicting the Intention to Use Mobile Banking in India Introduction. International Journal of Bank Marketing, 36 No. 2, 357-378.

[19]. Venkatesh, V., Morris, M. G., Davis, G. B., \& Davis, F. D. (2003). User Acceptance of Information Technology: Toward a Unified View. 27(3), 425-478.

[20]. Venkatesh, V., Thong, J. Y. L., Chan, F. K. Y., Hu, P. J. H., \& Brown, S. A. (2011). Extending the twostage information systems continuance model: Incorporating UTAUT predictors and the role of context. Information Systems Journal, 21(6), 527-555. https://doi.org/10.1111/j.1365-2575.2011.00373.x

[21]. Wessels, L., \& Drennan, J. (2010). An investigation of consumer acceptance of M-banking. International Journal of Bank Marketing, 28(7), 547-568. https://doi.org/10.1108/02652321011085194 